\title{
11. The Phantasmagoric Dispositif: An Assembly of Bodies and Images in Real Time and Space
}

\author{
Noam M. Elcott
}

\begin{abstract}
This essay aims to identify, historicize, and theorize an image-spectator relationship best characterized as phantasmagoric: the actual (or apparent) gathering of human beings and images in a single time-space continuum. The furst two sections locate phantasmagoria in relation to art, film, and their respective corpuses of criticism and theory. The third section situates phantasmagoria alongside two related dispositifs: the cinematic (images set at a distance) and the domestic (images enclosed in objects). The fourth section identifies the salient qualities of phantasmagoria in relation to corporeality, space, and time. The final section returns to the works of McCall, Whitman, Viola, Campus, and Oursler. The article demonstrates the importance of dispositifs - not only their subtle variations but also their stark and enduring differences.
\end{abstract}

Keywords: Phantasmagoria, film installation, video installation, Expanded Cinema, dispositif, media archaeology, spectatorship, augmented reality

\section{Resurrection Redux}

In this exhibition, a luminous figure-representing sometimes a skeleton and sometimes the head of some eminent person-appeared before the spectators, who were seated in a dark chamber. It grew less and less, and seemed to retire to a great distance. It again advanced and consequently increased in size, and having retired a second time, it appeared to vanish in

Sæther, S.Ø. and S.T. Bull (eds.), Screen Space Reconfigured. Amsterdam: Amsterdam University Press, 2020 DOI 10.5117/9789089649928_CH11 


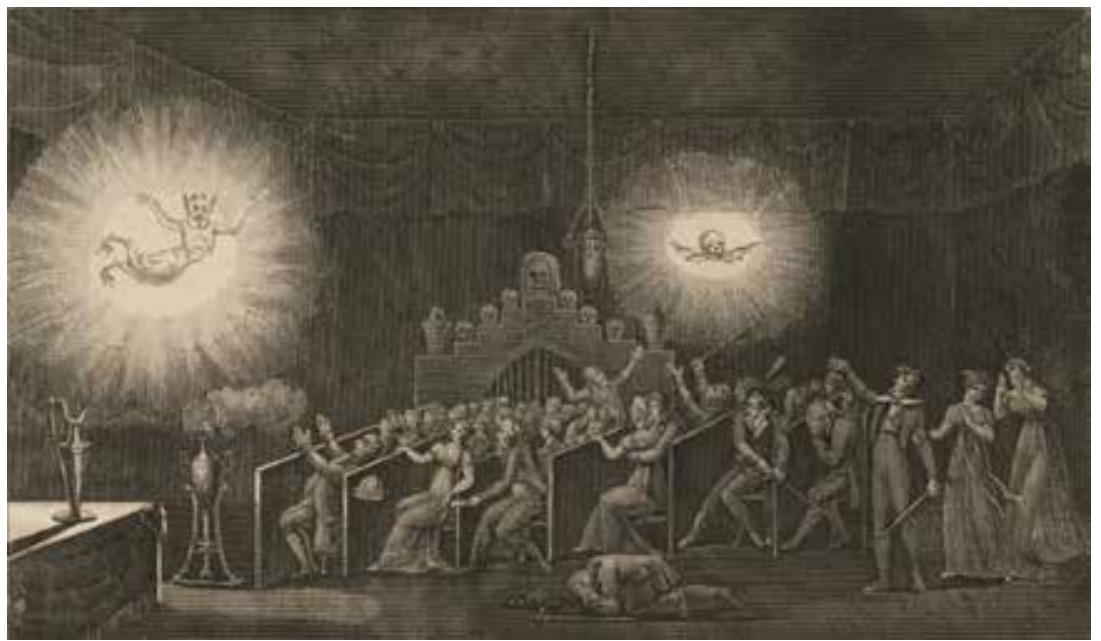

21. The Phantasmagoria, frontispiece from Étienne-Gaspard Robertson, Mémoires récréatifs, scientifiques et anecdotiques, 1831-1833.

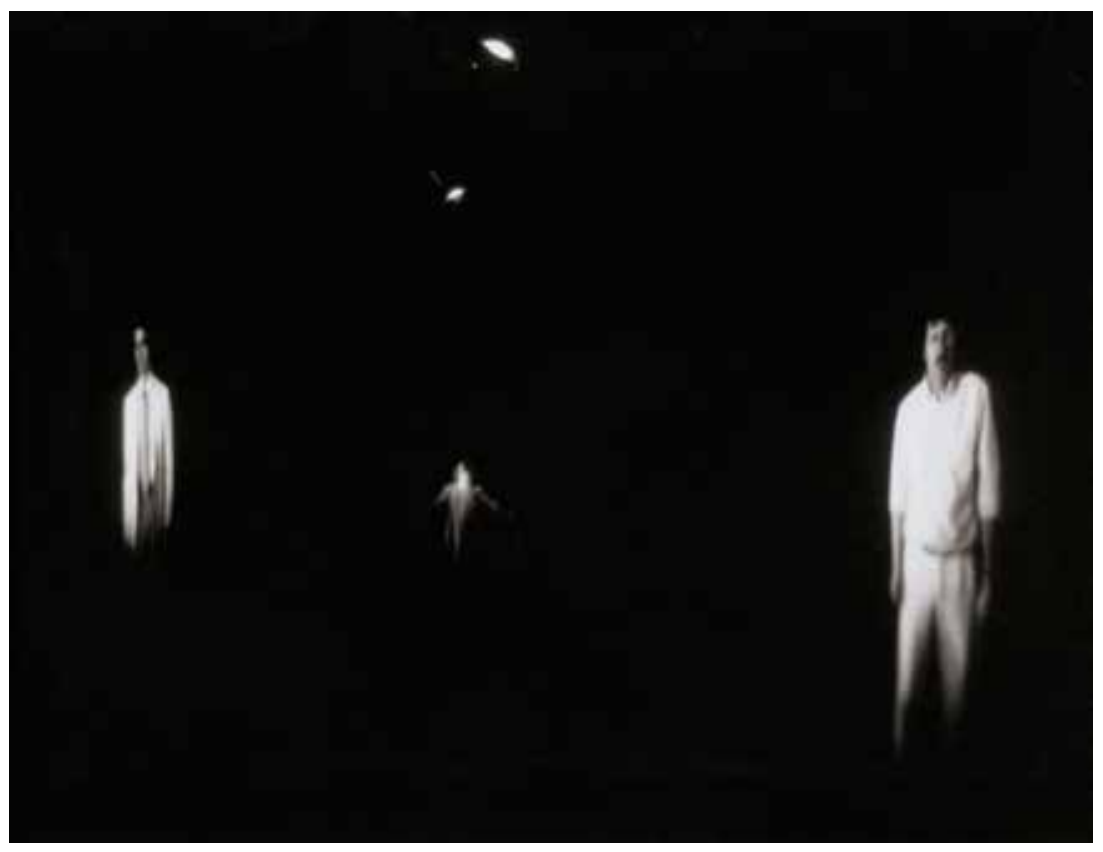

22. Gary Hill. Tall Ships, 1992. Detail from sixteen-channel video installation, silent, $10 \times 10 \times 90 \mathrm{ft}$. Photo: Mark B. McLoughlin. Courtesy of the artist. 
a luminous cloud, from which another figure gradually arose and advanced and retreated as before. ${ }^{1}$

The piece is a kind of cave- or underground-like hall—very dark [...] From an unseen source black-and-white images of twelve different people are projected all along the walls [...]. When you approach the image, say, of a distant seated person and stand before her or him, she or he responds to your presence by getting up and walking straight up to you, there to remain, 'life-size', for a longish period simply standing and looking at you. If you leave, or if you stand there too long, the person turns around and goes back to the original spot and sits down. ${ }^{2}$

Two exhibitions separated by two hundred years. The first premiered officially in 179os Paris — an earlier version was staged in Leipzig — and spread to European capitals like London. Part enlightened entertainment, part haunted house, the Phantasmagoria, like its descendant two hundred years later, refused categorization as mere magic lantern spectacle. ${ }^{3}$

It is not a frivolous spectacle; it is made for the man who thinks, for the philosopher. ${ }^{4}$

What may appear on one level as just another art world spectacle has a much deeper resonance, reaching through layers of careful decision making as to how the final effect might be incited within the phenomenology of viewing. ${ }^{5}$

The second exhibition, Tall Ships (1992), an installation by the video artist Gary Hill, premiered in Kassel, at Documenta IX, and was soon shown at the Whitney Biennial in New York (1993) and other international venues. As in the Phantasmagoria, a 'sepulchral' atmosphere pervaded the exhibition's

\footnotetext{
$1 \quad$ Brewster, Ferguson's Lectures, pp. 264-265.

2 Quasha and Stein, 'Tall Acts of Seeing', p. 189.

3 Robertson's Phantasmagoria was the most famous of several late- $18^{\text {th }}$ and early $19^{\text {th }}$-century attractions where spectators were immersed in darkness and ghoulish figures were projected on translucent screens or clouds of smoke such that they appeared to occupy the same space as the spectators. For an overview of the original phantasmagorias, see Mannoni, The Great Art of Light and Shadow, pp. 136-175.

4 Robertson, Mémoires récréatifs, p. 278.

5 Morgan, 'Gary Hill', p. 7.
} 
darkness. ${ }^{6}$ And the darkness, in turn, induced life-and-death encounters'one couldn't help intermittently fantasizing that these colourless, even wraith-like, yet curiously attractive figures were, as one imagines them, the recently dead, returning for some warmth of last contact with the living'-and, more crucially, fulfilled the technical requirement whereby the images abandoned the wall and entered, as quasi-animate beings, the same space as the spectators. ${ }^{7}$

One must paint a portrait of the deceased on glass with turpentine paints and (this is the principal point) cover the entire background of the drawn figure with thick, black oil paint. [...] The optical trickery is imperceptible; because the contour of the figure is covered in thick, black oil paint, no light is visible on the smoke except for that presented by the luminous image. ${ }^{8}$

In actuality the video image is a frameless continuum: in Tall Ships the images have been freed into the materiality of real time and space. ${ }^{9}$

He uses special lenses attached to suspended video monitors to blur out the frame of the image. That technical detail permits one not to see images but only people moving. In fact, one forgets the image as an image. ${ }^{10}$

Hill is much more inventive, especially in the relationships he creates between image and spectator. [...] There's no screen or frame around it—it's a projection from overhead—just this lit image on an otherwise dark wall. [...] it's difficult to treat these figures as merely images. ${ }^{11}$

[The images] patrol a similar territory to our own. [...] This Pygmalion fantasy $[. .$.$] brings into play the idea that pictures lead a life of their own. { }^{12}$

The wraith-like figures are not framed in paintings, elevated on pedestals, enclosed in television sets, or situated at an insuperable remove. Like phantasmagoric ghosts, the images gather in a dark space shared with spectators.

6 Robertson, Mémoires récréatifs, pp. 1, 278; Morgan, 'Missing Persons', p. 26.

7 Quasha and Stein, 'Tall Acts of Seeing', p. 191. The sentiment is echoed in nearly every review of the piece.

8 von Eckartshausen, Aufschlüsse zür Magie, pp. 129, 131.

9 Cooke, 'Gary Hill', p. 18.

10 Duguet in Balkema and Slager, Concepts on the Move, p. 176.

11 Lubbock, 'Is there someone out there?', p. 21.

12 Morgan, 'Missing Persons', pp. 22-23. 
Most critics failed to grasp the basic technical operations of Hill's installation. ${ }^{13}$ Fewer still discerned the $18^{\text {th }}$-century precedent. And even the scant links established between Tall Ships and the Phantasmagoria are at once too general- 'phantasmagoria' is made to stand in for illusion writ large-and too specific, tied solely to this strikingly analogous installation. ${ }^{14}$ The technical and historical lacunae are symptomatic of a broader deficiency: neither art history nor film studies recognize phantasmagoria as a fundamental configuration of image and spectator-one with deep media archaeological roots and myriad contemporary manifestations. Focused on individual media, technologies, genres, artists, movements, styles, or subjects, scholars have largely failed to recognize the decisive roles played by the coordinated disposition of these disparate elements in relation to specific modes of spectatorship. Phantasmagoria is one such dispositif.

Two exhibitions. Two hundred years. One set of reactions. One technical setup. In a word, one dispositif. ${ }^{15}$ Phantasmagoria or, more precisely, the phantasmagoric dispositive - the assembly, in a single space and time, of spectators and images (seemingly) freed from material supports-is an essential component of Hill's work and that of countless avant-garde film, video, and sound installations and performances. Robert Whitman's Shower (1964), Peter Campus's Interface (1972), Anthony McCall's Line Describing a Cone (1973), Bill Viola's The Sleep of Reason (1988), Gary Hill's Tall Ships (1992), and Tony Oursler's The Influence Machine (2000) are just a handful of the major and minor works best understood neither as paintings or sculptures nor as cinematic films but rather as phantasmagorias. No less important, we

13 As the above citations make clear, champions and detractors alike misunderstood the basic technical setup. The principal technical point - recognized by the $18^{\text {th }}$-century commentator but missed by the $20^{\text {th }}$-century critics - is that the figure be shot (or painted) against a black background; only then can the image be freed from the frame when projected in a dark environment by a hidden device. Hill says as much in Cornwell, 'Gary Hill', p. 225. In terms of the phantasmagoric dispositif, there is no fundamental difference between magic lantern slides and video technology. Indeed, Hill's video should not be considered an 'improvement' in the techno-teleological sense. Phantasmagoric slides were projected in vivid colour and were accompanied by a range of immersive sound effects; Hill's silent images were projected in nebulous black and white.

14 See, for example Hanhardt, 'Between Language and the Moving Image', pp. 115-116; Elwes, Installation and the Moving Image, p. 79 but also p.1. The tendency to generalize phantasmagoria as illusion has remained a constant from the $19^{\text {th }}$ century to the present. See, for example, Castle, Phantasmagoria, pp. 42-43 and passim. For a take on the Phantasmagoria and its current resonances that is more rigorous media archaeologically even as it is less interested in the finer points of contemporary art, see Grau, 'Remember the Phantasmagoria', pp. 137-161.

15 Within the rapidly expanding literature on dispositifs, see Albera and Tortajada, Cine-Dispositives. 
are witnessing an explosion in phantasmagoric technologies and techniques: immersive 'virtual realities' (which seem finally to have crossed the threshold of viability in devices like the Oculus Rift) and a range of 'augmented realities' (where images are superimposed on our vision of the real world) — above all, a miscellany of attractions and devices erroneously billed as 'holographic'. ${ }^{16}$ The worlds of art, cinema, and media are saturated in phantasmagoria. But because phantasmagoria cannot be tied to any one medium or technology, genre or subject, movement or epoch, we have failed to recognize its import.

As a specific attraction, the Phantasmagoria died out in the $19^{\text {th }}$ century. As a commonplace description - 'a series of imaginary (and usually fantastic) forms' or 'a shifting and changing scene consisting of many elements, esp. one that is startling or extraordinary' (OED) — phantasmagoria suffuses the world. ${ }^{17}$ What concerns us, however, is not any old razzle-dazzle, fantasy, or gore. Phantasmagoria is not just a subject or effect, much less an amusement confined to centuries past. Phantasmagoria is above all an operation: the actual (or apparent) gathering of humans and images through an assortment of techniques that for centuries have pervaded the worlds of art and cinema, theatre and spectacle. And yet we lack the critical terminology to describe the co-presence of images: not distant visions (like those proffered in the cinema) nor circumscribed pictures (like those enclosed in frames or television sets) but rather images that appear to abandon their material supports and enter our world. This essay aims to establish phantasmagoria as the precise term to describe an assembly of bodies and images in a shared time and space. The first two sections locate phantasmagoria in relation to art, film, and their respective corpuses of criticism and theory. The third section situates phantasmagoria alongside two related dispositifs: the cinematic (images set at a distance) and the domestic (images enclosed in objects). The fourth section identifies the salient qualities of phantasmagoria in relation to corporeality, space, and time. The final section returns to the motley artists and works named above and reveals their profound and multifaceted alignment toward phantasmagoria. At every turn, the essay demonstrates the importance of dispositifs - not only their subtle variations but also and above all their stark and enduring differences. Dispositifs alone may not determine our relationship to images, but their configurations of time and space, bodies and vision are decisive aspects of every work of art and every encounter with media.

16 On the technical and historical aspects of holography, see Schroeter, ${ }_{3} D$. On the cultural politics of 'holography', see de Bruyn, 'Empire's Hologram'; and 'Das Holografische Fenster', pp. 67-98.

17 Overviews abound. See, for example, Nead, The Haunted Gallery; Warner, Phantasmagoria. 


\section{Art Installations: Beyond Illusion and Anti-Illusion}

In the winter of 1798-1799, Étienne-Gaspard Robertson famously installed his Phantasmagoria in a Capuchin convent depopulated by the French Revolution. Yet this was hardly the first time that images were brought to life in sacred spaces. For centuries, as Giovanni Careri asserts, Baroque chapels were 'populated by bodies made of paint, marble, stucco, and flesh'. ${ }^{18}$ In the hands of Gian Lorenzo Bernini, the effects were positively phantasmagoric. No less an authority than Rudolf Wittkower states (and restates) as much in his seminal monograph, which warrants quotation at length. The Cornaro Chapel, centred around but not limited to The Ecstasy of Saint Teresa (1647-1652), instantiated the phantasmagoric confusion of reality and illusion like few works, prior or since.

Bernini made this scene real and visionary at the same time. [...] The vision takes place in an imaginary realm on a large cloud magically suspended in mid-air. [...] the group is bathed in warm and mysterious light, falling from above through a window of yellow glass hidden behind the pediment and playing on the highly polished marble surface of the two figures. [Cornaro family members flank the epiphany in trompe l'oeil boxes such that] the fictitious architecture and the architecture of the real chapel seem to interpenetrate. This creates the illusion that the Cornaro family is sitting in an extension of the space in which we move. [...] Like the Cornaro family, the worshipper participates in the supra-human mystery shown on the altar, and if he yields entirely to the ingenious and elaborate directives given by the artist, he will step beyond the narrow limits of his own existence and be entranced with the casuality of an enchanted world. ${ }^{19}$

Coloured and white marble, yellow glass and warm light, painted mural and stucco, gilded wood and gilt bronze - to reduce the work to 'sculpture' is to miss the mark. What's more, mysterious lighting from hidden sources, fictitious architectures, hyper-realism: these are the building blocks of phantasmagoria. In the Altieri, Fonseca, and Cornaro Chapels, Wittkower concludes, 'Bernini created a supra-real world in which the transitions seem obliterated between real and imaginary space, past and present, 
phenomenal and actual existence, life and death. ${ }^{20}$ One can hardly define phantasmagoria more succinctly.

The power of Bernini notwithstanding, the marginalization of phantasmagoria in avant-garde discourse is no accident. For the last fifty years, avant-garde art and film criticism has been mired in a series of binaries inherited from a particularly potent blend of 1970 s theory. Some combination of Minimalism's emphasis on phenomenology, post-Minimalism's exploration of process and institutional critique, and apparatus film theory's constitution of a cinematic subject has divided the world into good and bad objects: materiality and immateriality; embodiment and disembodiment; active participation and passive spectatorship; real space and illusionistic space; more broadly, reality and illusion; demystification and mystification; avant-garde art and Hollywood film. ${ }^{21}$ Even as the dominant movements of the 1960 and ' 70 s abandoned strict divisions between media, adopted projections and moving images, and foregrounded the physical presence of viewers, they did so overwhelmingly in opposition to illusions of any kind. ${ }^{22}$ In such discourses and practices, illusion is a four letter word; phantasmagoria is out of the question.

Critics have perpetuated the elision of perceptual illusion and ideological mystification by adhering to the derogatory omnibus 'phantasmagoria'. For Marxist critics in the mould of Theodor Adorno, phantasmagoria was and is tied to the occultation of production under capitalism and, as exemplified in the work of Richard Wagner, asserts 'the concept of illusions as the absolute reality of the unreal'. ${ }^{23}$ In such an intellectual climate, installation art—above all, film and video installations—could only be

20 Ibid., p. 159.

21 See Mondloch, 'Screens'; Rodowick, The Crisis of Political Modernism.

22 Consider, for example, the opening sentences of Peter Gidal's 'Theory and Definition of Structural/Materialist Film' (1976): 'Structural/Materialist film attempts to be non-illusionist. The process of the film's making deals with devices that result in demystification or attempted demystification of the film process.' Gidal, 'Theory and Definition', p. 1. Compare Andrew Uroskie's recent and striking analysis of Janet Cardiff and George Bures Miller's The Paradise Institute (2001): 'If the apparatus is foregrounded, it is not for the purpose of dismissing illusion and maintaining a contravening reality, but rather so as to throw our demarcation of reality and illusion into doubt.' Uroskie, Between the Black Box and the White Cube, p. 3.

23 Adorno, In Search of Wagner, pp. 85-96, here p. 9o. Noteworthy among numerous recent attacks waged against artworks deemed too phantasmagoric is T.J. Clark's invocation of Benjamin to conclude his assault on Tony Oursler's The Influence Machine: 'Modernity, as Benjamin reminds us, has thrived from the very beginning on a cheap spectacle of the strange, the new, the phantasmagoric. But modernity also truly dreams. The art that survives is the art that lays hold of the primary process, not the surface image-flow.' Clark, 'Modernism, Postmodernism, and Steam', p. 173. Several Benjamin scholars, to the contrary, have identified in his thought 
trumpeted under the banner of 'anti-illusion'. ${ }^{24}$ Yet the media archaeology of scholars like John Tresch and Tom Gunning demonstrates definitively that phantasmagoria cannot be reduced to a derogatory omnibus for cheap and illusory spectacles. ${ }^{25}$ Even as they define 'phantasmagoria' differently, Tresch, Gunning, and other scholars have laid the necessary groundwork for a renewed encounter with the concept of phantasmagoria stripped of its pejorative connotations. Indeed, it may very well be the pejorative designation that has blinded critics and historians to a crucial quality of so much recent art and media, a quality we can name-without judgment and with renewed media archaeological vigor-phantasmagoria: the assembly of humans and images.

\section{Cinematic Faith: Insufficient and Excessive}

The negative associations conjured by the term phantasmagoria have hindered its critical evaluation by scholars of avant-garde art and film. Its neglect has been compounded by the existential debates within cinema and media studies over the specificity or singularity of film. ${ }^{26}$ For phantasmagoria - whether that of Bernini, Robertson, or Hill—invariably evokes an expansive history of cinema and undercuts efforts to delimit the specificity of film. The battle often hinges on the status of the cinematic dispositif. Once the centrepiece of so-called apparatus theory, cinemas are now cast aside with abandon or fanatically conserved. ${ }^{27}$ We will address each position in turn. In 2006, philosopher Giorgio Agamben theorized the cell phone as a dispositif, a techno-political apparatus that was reconfiguring the human subject. ${ }^{28}$ Agamben's breezy analysis was at once too quick to ascribe major

the centrality of 'critical' or 'progressive' phantasmagorias. See Cohen, 'Walter Benjamin's Phantasmagoria', pp. 87-107; Jennings, 'On the Banks of a New Lethe', p. 104.

24 Consider the works gathered in the aptly named 'Anti-Illusion' exhibition at the Whitney Museum in 1969: paintings, sculptures, installations, compositions, and performances by Carl Andre, Robert Ryman, Eva Hesse, Steve Reich, Michael Snow, and others. Here, the co-presence of viewer and image aimed at the 'reversal of illusion' and 'inverse trompe l'oeil'. Monte, 'AntiIllusion', p. 7 and passim.

25 Tresch insist on 'the displacement, if not dissolution, of the line separating scientific truth from collective phantasmagoria', just as Gunning triangulates the dyad of enlightenment and mystification through the category of wonder. See Tresch, 'The Prophet and the Pendulum', p. 36; Gunning, 'Phantasmagoria and the Manufacturing of Illusions and Wonder', pp. 31-44.

26 See, for example, Andrew, What Cinema Is!.

27 See esp. Baudry, 'The Apparatus', pp. 299-318.

28 Agamben, What is an Apparatus? 
subject effects to a single apparatus and too slow to identify the radical transformations in mobile devices already underway. Concurrently, New Yorker film critic David Denby reported from the front lines of the mediaindustrial complex, which recognized in the video iPod, 'a new platform for movies, a new convenience that will annihilate old paradigms'. ${ }^{29}$ Now that smartphone and tablet users number in the billions and multi-platform video technology has become as hegemonic as cinemas were in their heyday, the 'new convenience' has assumed the status of a dispositif. In Denby's account, the most damning news was an evaluation not of media technologies but of media subjects: a new generation of cinema spectators or, more precisely, media consumers. 'According to home-entertainment specialists I spoke to in Hollywood', Denby writes, 'many kids are "platform agnostic" — that is, they will look at movies on any screen at all, large or small' $3^{30}$ Let's dwell for a moment on the phrase 'platform agnostic'. For if Denby's target was a generation of viewers - 'kids' - he borrowed the term from computing. According to the OED, a platform is 'a standard system architecture; a (type of) machine and/or operating system, regarded as the base on which software applications are run'. Adobe Acrobat and Firefox, to cite two among innumerable examples, are platform agnostic in so much as they can run on any computer platform, be it MS Windows, Apple OS, Linux, what have you. The term migrated from computer platforms to much wider-ranging media platforms and their consumers: cinema, television, desktops, laptops, tablets, smartphones are all equally valid platforms for the consumption of sounds and images by platform agnostics. Industry executives understood viewers - human beings - in terms of software and devices. Today, one is hard pressed to find a commercial campaign — let alone a movie — that is not cross-platform, that is, whose 'content' is not 'platform agnostic'. ${ }^{31}$ Platform agnosticism - the capacity to deliver and consume media content across multiple platforms - became the creed of software engineers, advertisers, politicians, organizers, and corporate and media gurus.

The backlash against platform agnosticism came swiftly. Companies are encouraged by some to focus on their core platforms and, much more relevant to us, film and art theorists are evangelizing, with renewed vigor, essentialist strains of specificity and materiality—a willful blindness to the

29 Denby, 'Big Pictures', p. 54.

30 Ibid.

31 Artists have followed suit. Stan Douglas, for example, recently premiered a new multimedia theatre work, Helen Lawrence (2014), which was preceded earlier that year by Circa 1948, a $3^{\mathrm{D}}$-augmented reality app available for iOS devices. (Presumably only funding limitations impeded an Android OS version; accordingly the app is not truly platform agnostic.) 
epochal change unfolding around us. Cinema studies or art history, we are often told, must be saved from the perdition of media and visual studies. Celluloid, others preach, must not only be preserved but upheld against video and digital pretenders. A third claim pertains to the location, place, site, or, more expansively yet more precisely, the dispositif of cinema. Among the most passionate spokesmen for the essential primacy of the cinematic dispositif is film theorist Raymond Bellour:

I begin from a simple hypothesis, but one involving infinite detours: the lived, more or less collective experience of a film projected in a cinema, in the dark, according to an unalterably precise screening procedure, remains the condition for a special memory experience, one from which every other viewing situation more or less departs. This supposes a certain rule of faith of which the spectator would be the incarnation, in the unfolding of a liturgy associated with film, with cinema, and with film in the cinema situation. $^{32}$

Bellour counters platform agnosticism with an article of cinematic faith, a liturgy of film, a hypothesis with infinite detours, all of which, however, follow the same orthodoxy. The failure of this orthodoxy is not its insistence on the specificity of the cinematic dispositif but the pronouncement of its timeless primacy, the condition 'from which every other viewing situation more or less departs'. Where platform agnostics are willfully ignorant of dispositifs and reduce cinema - and other media - to mere 'content', platform zealots are willfully ignorant of the historical contingency of movie theatres and hypostatize classical theatrical cinema into a medium-specific essence.

But, as Jonathan Crary has recently noted, cinema as a dispositif was relatively fixed only from the late 1920 s through the 1960 s and television

32 Bellour, 'The Cinema Spectator', p. 9. He later argues that 'The only inviolate element is the dispositif. The theatre. The darkness. The fixed time of the screening [...]' (p. 14). Bellour's account is informed and nuanced; but it ultimately hinges on the unresolved contradiction whereby 'the dispositif of cinema is historical, it is also transhistorical'. Bellour, 'La querelle des dispositifs', p. 18. In the Foreword to the recent English translation of L'entre-images, Bellour spells out his about-face in regard to specificity-where he earlier tore down divisions between theatrical cinema and installation art, he now asserts the specificity of the cinematic dispositif. In Bellour, Between-the-Images, p. 11. Francesco Casetti has also explored the phenomenon extensively. As his preferred term - 'relocated cinema' - attests, Casetti also anchors the experience of film in the cinema. But Casetti aims not at retaining theatres as the primary site of cinematic reception but rather at theorizing the cinema to come. See Casetti, 'Elsewhere', pp. 348-351; Casetti, 'Cinema Lost and Found'; Casetti, 'Back to the Motherland', pp. 1-12; Casetti, The Lumière Galaxy, pp. 17-42. 
in the US only from the 1950s into the 1970s. The perceived permanence of certain key features, he argues, 'allowed critics to expound theories of cinema, television, or video based on the assumption that these forms or systems had certain essential self-defining characteristics. In retrospect, what were most often identified as essential were temporary elements of larger constellations whose rates of change were variable and unpredictable. ${ }^{33}$ Our charge as historians and theorists is to recover and conceptualize the stark variables and unexpected continuities in these larger media constellations, a task wholly abandoned by platform agnostics and platform zealots alike. Both zealots and agnostics render history and politics irrelevant: the first group does so by universalizing the cinematic condition into religion, the other by annulling it into content. Our charge, finally, is not to find the essence of cinema or delimit its specificity but rather to conceptualize its multiplicity. In its long history - what is often described as its pre- and post-history-cinema has always engendered a multiplicity of sites and a multiplicity of images. Cinemas and film simply constituted the dominant iteration in the medium's classical period. But cinema is no more tied to movie theatres and celluloid than sculpture is bound to temples and marble. In a word, cinema will be multiple or it will not be at all.

\section{Cinematic. Domestic. Phantasmagoric.}

The multiplicity revolves around dispositifs in which moving images have thrived, to varying degrees, over the last few centuries. This typology advances from the media archaeological observation that certain types of images thrive best in certain types of locations-and not in others. For the sake of simplicity, consider a three-fold multiplicity: three media dispositifs that promote and inhibit specific types of images in specific types of locations. Each dispositif is internally multifaceted and externally porous to other dispositifs. Claims to their coherence and strict delineation are heuristic. But violations of these boundaries have real consequences: aesthetic, social, economic, perhaps even political. We will distinguish the three dispositifs as the cinematic, the domestic, and the phantasmagoric.

The cinematic is an emblematic instance of what Joachim Paech has described as the experience of proximity effected through distance. ${ }^{34}$

34 Paech, 'Eine Dame verschwindet', especially p. 777. Some of the media archaeology in this section builds on research developed in my book, Artificial Darkness. 
Cinema places us in the film by displacing us from the auditorium. As an architecture, system, or dispositif that effects proximity through distance, the cinematic arose wholly independent of film. (Conversely, in their first decade, like today, movies were not inextricably bound to purpose-built theatres.) Radical spatial dislocation and separation constituted one of the core qualities of $19^{\text {th }}$-century attractions. Barker's Panorama, Daguerre's Diorama, the Kaiserpanorama, the Kinetoscope, the cinema of Edison or the Lumières, and, above all, Wagner's theatre at Bayreuth produced, as Crary argues, 'the image as an autonomous luminous screen of attraction, whose apparitional appeal is an effect of both its uncertain spatial location and its detachment from a broader visual field'. ${ }^{35}$ Among these attractions, Wagner's theatre at Bayreuth was exemplary on two separate counts. First, it was universal. The Panorama, Diorama, Kaiserpanorama, and Kinetoscope were proprietary structures built for the exhibition of specific image types. (Note the frequent proper nouns and patents.) The Kaiserpanorama, a late $19^{\text {th }}$-century device that enabled up to 25 individuals to view a series of stereoscopic images, could not display Panoramic paintings, which measured thousands of square feet, any more than a Diorama could exhibit the $35 \mathrm{~mm}$ filmstrips that ran through the Kinetoscope, Edison's early cinematic peepshow device. The exhibition structures required specific technical images, and the images required specific technical exhibition structures. Wagner's Festspielhaus, by contrast, was a model theatre that could accommodate countless types of performances and images. Indeed, its most significant legacy was its adoption by cinemas, that is, as a support for a medium as yet unrealized in 1876 .

Second, Wagner theorized spectatorial displacement more radically than any other $19^{\text {th }}$-century figure. His essay 'The Art-Work of the Future' became the touchstone, directly and indirectly, for countless $20^{\text {th }}$-century theories of cinema:

In the arrangement of the space for the spectators the need for optical and acoustic understanding of the artwork will give the necessary law [...]. Thus the spectator transplants himself upon the stage, by means of all his visual and aural faculties; while the performer becomes an artist only by complete absorption into the public. [...] the public, that representative of daily life, disappears from the auditorium completely, and lives and 
breathes now only in the artwork which seems to it as Life itself, and on the stage which seems the wide expanse of the whole World. ${ }^{6}$

Wagner's turn-of-the-century translator, William Ashton Ellis, could not equal the Master's temerity and wrote that the public 'forgets the confines of the auditorium' rather than 'disappears' from the auditorium. But viewed retrospectively from the rise of cinemas, disappearance was not too strong a word. Proximity effected through distance is the hallmark of cinema as a dispositif. Cinematic immersion necessitates the displacement of spectators from their environment.

'Consider, on the other hand, the opposite experience, the experience of TV, which also shows films: nothing, no fascination; the darkness is dissolved, the anonymity repressed, the space is familiar, organized (by furniture and familiar objects), tamed.'37 Thus Roland Barthes compared cinema and television - the signature media for the cinematic and domestic dispositifs. The domestic implies not only the home but also, as betrayed by its French etymology, a household servant. Whether at home, at work, or on the move, we are pampered and besieged by devices that ring and vibrate, speak and listen, take and stream and play videos; they know where we are and remind us what to do and respond to our commands; they facilitate and carry out our virtual work, survey nearly every facet of our lives, and perform innumerable other tasks once carried out by domestics. ${ }^{3}$ Domestic media devices thus most readily earn their name in the present. But they reach back to the $19^{\text {th }}$-century salon, which harboured not only paintings and prints but also phenakistoscopes, praxinoscopes, and other optical toys. The domestic is also the middle class living room where television made its home, first as furniture, later as hearth. Domestic are the tract houses, apartment complexes, and McMansions littered with computers, tablets, phones, and other devices for the consumption of media content, not least - though quite nearly least — movies. Domestic are the ever increasing number of galleries from the 1960 s to the present in which altered television sets by Nam June Paik, ornate celluloid loops by Simon Starling, and the cinematic and videographic sculptures of countless others found quarters and, eventually, buyers, who bring the works home. In the domestic, cinema

36 Wagner, 'The Art-Work of the Future', p. 185; Wagner, Das Kunstwerk der Zukunft, pp. 188-189. Translation modified. The pertinent original German reads: 'aus dem Zuschauerraume aber verschwindet das Publikum, dieser Repräsant des öffentlichen Lebens, sich selbst'.

37 Barthes, 'Upon Leaving the Movie Theatre', p. 2.

38 On service and servants, see Krajewski, 'The Power of Small Gestures', pp. 94-109. 
is an optical toy, a piece of furniture, a book, a sculpture-in a word, an object. Accordingly, it is placed among other objects. Crucial is that devices like televisions do not create the same sense of placelessness as cinema. As Anna McCarthy argues: 'the idea that the television apparatus is itself an encroaching force of placelessness is a flawed, dangerously fetishistic one. The language of placelessness makes us forget that television is an object and, like all objects, it shapes its immediate space through its material form.'39 What's more, domestic 'cinema' is an object that, like nearly all capitalist objects, is made to be bought and sold. The domestic houses commodities. In the domestic, cinema finds a place as a commodity. Its vernacular forms range from toys to televisions and other electronic or digital gadgets; its culturally exalted forms we call artworks.

Like the cinematic and the domestic, the phantasmagoric is neither medium-specific nor platform agnostic. Unlike cinema and television, phantasmagoria never attained a classical form or a normative discourse. Indeed, the phantasmagoric dispositif emerges uncomfortably alongside the cinematic and the domestic. ${ }^{40}$ It is less familiar, but by no means less important, to contemporary spectators and viewers. So what is the phantasmagoric? Let's begin with what it was. Coined at the end of the $18^{\text {th }}$ century, the Phantasmagoria, as its name announced, assembled ghosts. Whether assuming the shape of a bloody nun, Medusa, the devil, or that of recently deceased leaders like Louis XVI or Robespierre, these ghosts were first and foremost mediated images. Phantasmagoric images were projected onto visible smoke or invisible screens suspended in dark spaces; they were unmoored from their material supports and occupied the same dark space as spectators. The original phantasmagorias were developed by enlightened showmen and duplicitous necromancers like Johann Schröpfer, Paul Philidor, and, most famously, Étienne-Gaspard Robertson. Their most

39 McCarthy, 'From Screen to Site', p. 96.

40 The museum director's introduction to Projected Images, an unheralded but important 1974 exhibition at the Walker Art Centre, frames the term 'projected images' in a manner similar to the phantasmagoric, that is, as a third term outside the cinematic and the domestic: 'While filmmaking and video production attract an increasing number of artists, most of these converts observe the technical conventions of the new media; their films are intended for viewing under standard projection conditions [= the cinematic] and their videotapes are made to be seen on television monitors [= the domestic]. By contrast the artists represented in this exhibition conceive of film and video images essentially in environmental terms - as dominant elements of interior spaces - and they are as much concerned with the changing spatial and psychological relationships between observer and image as with the character of the image itself.' Friedman, 'The Floating Picture Plane', p. 6. The exhibition featured works by Peter Campus, Robert Whitman, and other artists with strong affinities to the phantasmagoric. 
important descendant was the mid-1 $9^{\text {th }}$-century attraction named Pepper's Ghost, after the rational entertainer John Henry Pepper, a longtime lecturer and honorary director of London's Royal Polytechnic Institution. John Henry Pepper reaped a fortune from the Ghost, but he invented none of the elements in the device that would eventually bear his name.

The Ghost's seminal features were invented by Henry Dircks. And they derived, as suggested by Dircks's preferred designation - the 'Dircksian Phantasmagoria' - from the Phantasmagoria. To be all too brief, Pepper's Ghost or the 'Dircksian Phantasmagoria' comprised a giant, slanted pane of glass placed on stage such that an unawares audience could peer through the glass to the action on stage and simultaneously see a reflection in the glass of an actor in the wings (or below). Pepper's Ghost was briefly fused with film in attractions such as Oskar Messter's Alabastra, patented in 1910, variants of which were known as Kinoplastikon and Tanagra. The technique is the basis for nearly all the recent applications erroneously dubbed holographic: 'augmented reality' spectacles (eyewear) like Microsoft's HoloLens and Google Glass as well as mass spectacles for live and mediated audiences such as a 2012 Coachella concert that featured Tupac Shakur-who was murdered in 1996 but nonetheless 'appeared' onstage with Snoop Dogg, Dr. Dre, and other flesh-and-blood stars-and the 2014 resurrection of Michael Jackson at the Billboard Music Awards, where he performed a new song, 'live' on stage..$^{41}$ Over the course of 220 years, we have exchanged Robespierre and the Revolution for Tupac and hip hop, the slayer of kings for the King of Pop, but the techno-spatial configuration of phantasmagoria- that is, the phantasmagoric dispositif-has remained surprisingly stable.

In phantasmagorias, there is no radical separation between media images and human bodies; that, as we know, is the domain of the cinematic. Nor are the images contained within objects, as in the domestic. In the original $18^{\text {th }}$-century phantasmagorias and their contemporary descendants, humans and images are assembled in a common space and time. Whether these humans are credulous dupes or highly trained actors is of little consequence. Phantasmagorias are highly efficacious. We need not believe in ghosts to perceive phantasmagoric images. But phantasmagorias are also highly precarious. Here, cinema is strategically emplaced, like a weapon, to be deployed with unerring precision or risk exposure and failure. Phantasmagoria is a matter of performance or, more broadly, theatre, where living beings and mediated images can assemble.

41 More recently, a 'holographic' performance by the Chicago rapper Chief Keef was shut down by police. See Coscarelli, 'Hologram Performance'. 


\section{Bodies, Spaces, Times}

Displacement. Placement. Emplacement. But not re-placement. Cinema is not replaced by phantasmagoria, it is emplaced therein. Nor is it replaced by television or tablets; it is placed in domestic devices and spaces. As this porosity or fluidity attests, the divisions between displacement, placement, and emplacement are not quite as neat as this terminological triumvirate might suggest. And yet each dispositif gravitates toward specific and interlocked configurations of embodiment, space, and time.

The cinematic negates spectatorial space, the better to allow images to work on spectators. The domestic consents to space, the better to preserve the objects, which house the images. The phantasmagoric reconfigures extant space, the better to fuse objects, spectators, and images. In the cinema, we tend to forget not only the surrounding space but also our bodies. With Wagner, we remember, 'the public, that representative of daily life, disappears from the auditorium completely'. Exceptional genres-pornography, say, or horror - that engage our bodies directly are just that: exceptions that tend toward the phantasmagoric. ${ }^{42}$ Where bodily awareness is exceptional in the cinema, a cinematic sense of disembodiment is less likely on a couch before a TV set, with a smartphone or phenakistoscope in your hand, or in a brightly or even dimly lit art gallery. As Peter Campus noted in 1974: 'The monitor is an object sitting rigidly in space. [...] Compare this to a movie theatre where every effort is made to erase one's ability to locate the screen in the viewer's space. 43 If the cinema, according to 1920 f film theorist Rudolf Harms, should 'guarantee the highest degree of bodily detachedness and seek to alleviate the shortcomings of the individual's fixed and local bondedness', then domestic spaces welcome couch potatoes, gallery-goers, and other forms of quotidian and bathetic embodiment. ${ }^{44}$ (Why ever these forms of mundane embodiment were aligned with corporeal plenitude in the reception of Minimalism and related art movements will be a matter for future art historians to disentangle.) It is phantasmagoria, once again, that poses the least familiar and most unsettling form of spatiality and embodiment among the dispositifs in question. Here we are often hyperaware of our

42 Symptomatically, the first breakout $3 \mathrm{D}$ film, House of Wax (1953), was nothing if not a tale about phantasmagoria rendered quasi-phantasmagorically—that is, a tale about the confusion of humans and images rendered through the extension of images into spectatorial space. On the 'excessive mimesis' in House of Wax, see Siegert, 'Die Leiche in der Wachsfigur, especially', pp. 151-154.

43 Campus, 'Video as a Function of Reality', p. 82.

44 Harms, 'Philosophie des Films', p. 60. 
bodies and surroundings. In a reversal of the cinematic, the phantasmagoric must guarantee the highest degree of image detachedness - that is, it must unmoor images from any material support, including screens-in order to enhance their local bondedness. The phantasmagoric image, in other words, cannot be perceived as trapped inside a device or on a screen, nor as absolutely separated from the space we inhabit; rather, the phantasmagoric image must occupy the same space we occupy.

Each dispositif also requires and engenders a specific temporality. The cinematic is most effective as fixed duration or 'feature length'. We are willing to forget our bodies and our surroundings—-but not indefinitely. As Andy Warhol noted in relation to his early, long-duration films like Empire (1964): 'My first films using the stationary object were also made to help the audiences get more acquainted with themselves. ${ }^{45}$ Conversely, in order to turn cinema into an object, it is essential that duration be evacuated to the greatest possible degree. The duration of the image becomes a property of the objects. The results-familiar from living rooms and art galleries-are open-ended flow and short loops. The former is epitomized in closed-circuit feeds or continuous television programming. ${ }^{46}$ The latter is evident in devices such as phenakistoscopes and zoopraxiscopes as well as GIFs and other image formats. Video artists from the 1970 s to the present have employed and problematized both techniques: the close-circuit camera aimed at a Buddha statue in Nam June Paik's TV-Buddha (1974), the feverish loops in Dara Birnbaum's Technology/Transformation: Wonder Woman (1978-1979), or the confounding loops in Stan Douglas' Inconsolable Memories (2005), which disturb the 'this is where we came in' relationship to film and video installations (and recall an earlier moment of cinematic spectatorship, where entrances and exits were less policed). Lastly, the temporality of phantasmagoria is real time. Phantasmagorias may call up the dead or predict the future, as Thomas Elsaesser has observed, but for the spectator, 'the senses are anchored and the body situated in a "here and now"'. 47 Real time, of course, means more than the here and now. And the recent rise of phantasmagoria cannot be divorced from the ascendance of video, computers, and other real-time imaging systems. In Paul Virilio's sweeping account, the image has obeyed several fundamental logics or logistics in

45 Warhol in Gidal, Andy Warhol, pp. 92-94.

46 In Raymond Williams' famous formulation: planned flow is 'perhaps the defining characteristic of broadcasting, simultaneously as a technology and as a cultural form'. Williams, Television, p. 86.

47 Elsaesser, 'Between Knowing and Believing', p. 70. 
the last centuries: the formal logic of painting, engraving, and architecture, which ended in the $18^{\text {th }}$ century; the dialectical logic of photography and film of the $19^{\text {th }}$ and early $20^{\text {th }}$ centuries; and the paradoxical logic of video recording, holography, and computer graphics, beginning after the Second World War. Under the current reign of paradoxical presence: 'the real-time image dominates the thing represented, real time subsequently prevailing over real space, virtuality dominating actuality and turning the very concept of reality on its head'. ${ }^{8}$ What remained exceptional in Bernini's Cornaro chapel and Robertson's Capuchin convent is now a generalized condition. Revelers at Coachella and wearers of HoloLens-like visitors to Bernini's Saint Theresa, Robertson's Phantasmagoria, and Hill's Tall Ships - experience media images and real bodies, their own and those in trompe l'oeil boxes and on real stages, as part of a shared space-time continuum. Paradoxical presence inheres in the longue durée of phantasmagoria; but the postWWII explosion of paradoxical presence may conversely explain the recent rise of the phantasmagoric: no longer a series of isolated attractions but a fundamental—perhaps the fundamental—image logic of our time. When real time prevails over real space, real space becomes phantasmagoric, an assembly of bodies and images. ${ }^{49}$

\section{Three Pathways into the Phantasmagoric}

The phantasmagoric dispositif has been foundational for art, film, video, and theatre since the 1960 s. But because it often crossed the boundaries of established media or art forms like painting, film, or theatre, it has remained largely hidden in the historical record. Three exchanges are especially pronounced. The first is the expansion of cinema into performance, sculpture, or installation, as evident in Expanded Cinema and exemplified in the Solid Light films of Anthony McCall. The second is the introduction of film and video into sculpture and theatre, as perfected in the 'Cinema Pieces' and 'Theatre Works' of Robert Whitman. And finally, there is the phantasmagoric in video installations, like those of Bill Viola or Peter Campus. We will address each phantasmagoric practice in turn.

48 Virilio, The Vision Machine, p. 63.

49 Campus encapsulated this logistical reversal to conclude his 1974 statement: 'In a closedcircuit video situation one is no longer dealing with images of a temporally finite nature. The duration of the image becomes a property of the room.' Campus, 'Video as a Function of Reality', p. 83 . 


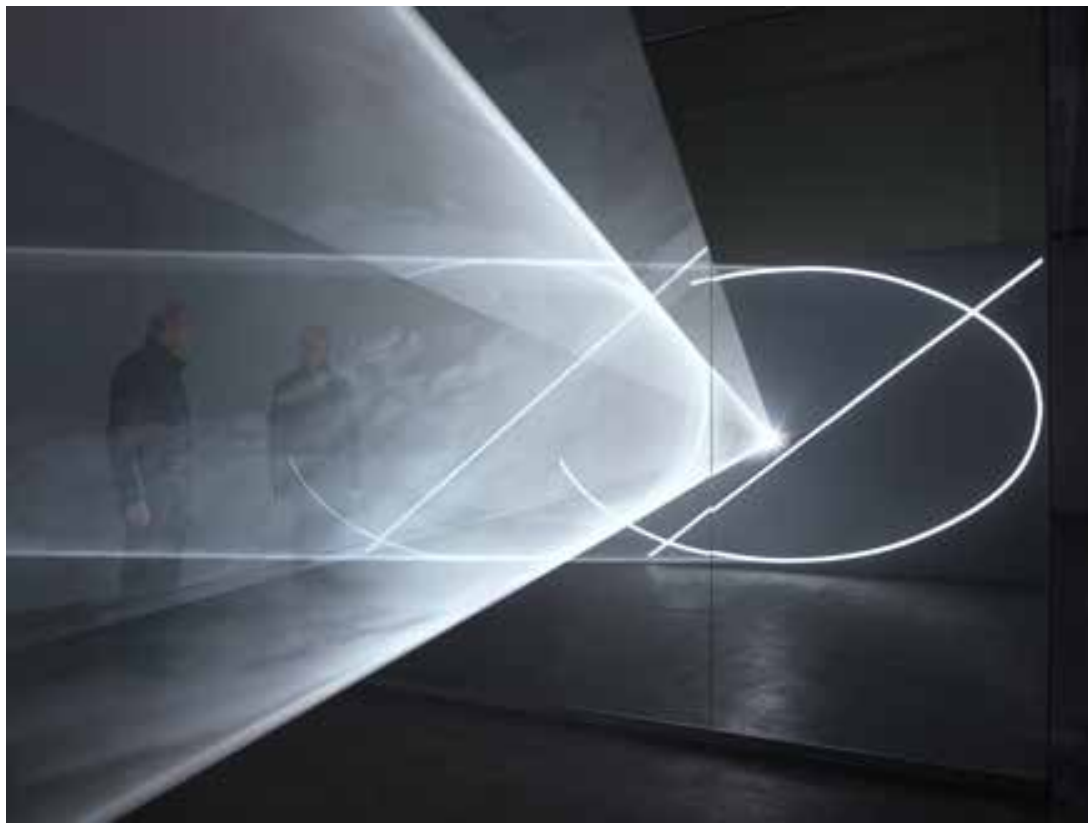

23. Anthony McCall. Split Second (Mirror), 2018. Installation view, Sean Kelly Gallery, New York. $\odot$ Anthony McCall. Photo: Dan Bradica. Courtesy of the artist.

Beginning with his now-canonical Line Describing a Cone (1973), Anthony McCall's Solid Light films comprise the projection of two-dimensional geometric forms through a misty and darkened space such that the beam of light is perceptible as a three-dimensional, immaterial sculpture.

McCall himself has situated his practice at the intersection of film, sculpture, and drawing. Recent critics have framed his work as a 'radical co-articulation of film and sculpture, as Gilles Deleuze might have put it, rather than a dialectical development leading from sculpture into film..$^{50}$ In the immediate context of Expanded Cinema and post-Minimalism, a radical co-articulation of film and sculpture was not only aesthetically but also politically ambitious in terms of its assault on traditional cinema spectatorship. In McCall's decisive 1974 statement: 'It is the first film to exist solely in real, three-dimensional space. [...] It refers to nothing beyond this real time.' He parried spectatorial immobility with a '[viewer who] can, indeed needs to, move around relative to the slowly emerging light form'. What's more: 'The viewer watches the film by standing with his or 
her back toward what would normally be the screen. ${ }^{.51}$ According to these searing statements, McCall's solid light films negated core aspects of the cinematic apparatus. That is, they were understood in largely negative terms. But in the longer history of dispositifs, the Solid Light films were and remain unambiguously phantasmagoric: projections on smoke in darkened spaces that assemble humans and images. As Gunnar Schmidt argues, McCall's Line Describing a Cone is 'a new combination of modern abstraction and premodern theatricality'.52 Two hundred years and a host of social, political, epistemological, and aesthetic ruptures separate the original Phantasmagorias from Line Describing a Cone and other Solid Light films, including a range of recent digital works projected vertically down from the ceiling. But the configuration of images and bodies, the common space-time continuum, and the experience of an immediate mediation (or paradoxical presence) belong neither to cinematic film nor to domestic sculptures, nor even to their co-articulation, so much as it adheres to the dicta established by the Phantasmagoria over two hundred years ago. The establishment of techno-aesthetic precedent does not diminish the radicality of the work. Quite the contrary. In light of the phantasmagoric dispositif, we can recognize in the work of McCall and others not only a reactive, negative relation to traditional artistic mediums like film and sculpture but also a positive engagement with the struggles of contemporary mediated existence. For what was a minor attraction two hundred years ago has become a generalized dispositif in our time.

Loosely affiliated with Happenings, Fluxus, and Expanded Cinema, the work of Robert Whitman plots a second trajectory into the phantasmagoric. Whitman's encounter with phantasmagoria proceeded from the opposite direction as McCall's, namely through the introduction of cinema into sculpture and theatre. Whitman's cinematic installations, or, as he called them, Cinema Pieces, are now among the best known and most striking phantasmagoric works from the 1960s. In Window (1963), Dining Room Table (1963), and Shower (c. 1964), Whitman fuses real objects and projected images to confuse, at least temporarily, reality and illusion. In Shower, to cite the locus classicus of phantasmagoric sculpture, a film of a woman showering

$5^{1}$ McCall, 'Two Statements', pp. 250-251. In 2003, when McCall republished the statement in October, he did not soften the stance so much as introduce room for productive confusion. No longer did the film exist solely in real, three-dimensional, space. No longer was it necessary to contrast his solid light film with films that 'allude to a past time'. With thirty years' hindsight, Line Describing a Cone at least hinted at the possibility of other times and places. Mediation crept into the work's primal immediacy. See McCall, 'Line Describing a Cone', pp. 42-62.

52 Schmidt, Weiche Displays, p. 27. 
is projected inside an operating shower, enclosed by a shower curtain and built into a wall in a dark space. The film is back projected-like the original Phantasmagoria-such that the projector is doubly screened off from the viewer: first by the translucent screen, second by the translucent shower curtain. Whitman effects a collapse of illusion and reality as the composite image received by the viewer is produced by virtual images projected on the first screen and drops of real water projected on the second. The famous and widely disseminated photograph of Shower maximizes its trompe l'oeil impact. But in short order, the looped film belies the illusion. Shots of the full-length nude are replaced by close-ups of body parts, mist, and the shower head, which sprays water first and then dark paint. As we return to the full-length nude, now dripping in paint and redolent of the Abstract Expressionist techniques still very much in vogue, we have crossed the boundaries of sculpture, cinema, and painting. More precisely, we have witnessed the Berniniesque, phantasmagoric mobilization of multiple media to fuse images and bodies in one and the same space and time.

Whitman's case should be an obvious one. His work has long been identified with 'a complete mesh of illusion and reality' (Richard Kostelanetz) ${ }^{53}$ and 'actual $[\mathrm{sic}]$ holographic images of oneself floating in three-dimensional space in real time' (Gene Youngblood). ${ }^{54}$ More recently, curators like Lynne Cooke and scholars like Branden Joseph and Andrew Uroskie have labeled Whitman's work 'phantasmagoric' or 'phantasmal', though not necessarily in the media archaeological sense advanced here. ${ }^{55}$ And yet critics invariably assign competing media to various elements within a given work-'a complex interplay of the sculptural, the pictorial, and the filmic'56 — when the varied media and techniques are better understood as a coordinated manifestation of the phantasmagoric.

Such is certainly the case in Whitman's performance pieces or, in his preferred terminology, Theatre Works, most illustriously Prune Flat (1965), a work that refuses categorization as cinema or theatre, painting or sculpture.

53 Kostelanetz, The Theatre of Mixed Means, p. 229. But note the context in the conversation with Whitman:

Kostelanetz: 'When the image flashed off the audience gasped. I thought this was a marvelous sign of the effectiveness of your deception, but it never happened again - such a complete mesh of illusion and reality. Wouldn't this be worth attempting to realize every night?' Whitman: 'I think that is nice, but it isn't crucial. I don't think that's what the piece is about.' 54 Youngblood, Expanded Cinema, p. 416.

55 Cooke, 'Through a Glass, Darkly', p. 64 and passim; Joseph, 'Plastic Empathy', p. 74 and passim; Uroskie, Between the Black Box and the White Cube, p. 141 and passim.

56 Cooke, 'Through a Glass, Darkly', p. 66. 
Prune Flat premiered at the Expanded Cinema Festival in New York and continued in an off-Broadway run, an exceptional development within Whitman's milieu. In previous Theatre Works, like American Moon (1960), the audience was segregated into small coves or bays that opened onto the performance space. At the Film-Makers' Cinematheque, which hosted the 1965 Expanded Cinema Festival, the shallow proscenium stage encouraged a more traditional theatrical format but also enabled the confusion of the illusory depth on screen and real flatness on stage. Approximately 50 minutes in length, Prune Flat embraces at turns the cinematic-a film is projected onto a large screen at the front of the theatre-and the domestic - objects are handled on the shallow stage..$^{57}$ But the bulk of the piece mingles live bodies and projected images in a manner that can only be described as phantasmagoric. Two women in white outfits appear variously on screen and on stage. A third, labeled 'movie girl', also wears white. But rather than double an on-screen presence or camouflage into the projection, she becomes a human screen for a second projector and film. Movie girl performs mundane actions: she stands, sits, smokes a cigarette, and, most conspicuously, dresses and undresses, often changing into or out of whole outfits instantaneously. The actress who plays movie girl never changes her white smock dress, which serves as the screen. Instead, her own film image - at least in the initial performance-is projected back onto her. Synchronization between the actress and the projection ensures the confusion of body and image; the comparatively simple magic of montage facilitates the quick outfit changes (a classic stage magic routine that otherwise requires great skill). At the speed of 24fps, a green dress turns red, then blue; a black dress vanishes to reveal a nude woman; the nude suddenly wears black undergarments; she struts across the stage, pounces, and immediately sports a red dress. The two screens-architectural and human-share a single technology (film projection) and technique (montage). In the first instance, the effect is cinematic (proximity through distance); in the second, it is phantasmagoric (an assembly of humans and images).

In Prune Flat, however, cinema is emplaced imprecisely. Part necessity, part design, the performer can never align herself perfectly with the projection; a ghostly doubling is visible unremittingly. The phantasmagoria itself

57 Whitman alluded to some of the contradictory impulses in the work: 'I suggested in the piece itself that it was about movies. [...] I want people to understand that [the stage] world was manufactured. It is an object world.' Whitman in Kostelanetz, The Theatre of Mixed Means, pp. 224-225. 
is haunted, a paradoxical presence that, as Branden Joseph argues, cannot be divorced from real-time techniques:

Prune Flat splits time in much the same way as it virtualizes space. Irreducible to the pop art embrace of the simulacrum, Whitman's 'real time' is also not the phenomenological time of minimal sculpture, which opposed the spectator's physicality against its spectacular expropriation. [...] Whitman's time is a 'real time' presented directly despite the mediation of images, or, as he insisted, presented directly, and in 'depth', because of that very mediation. Whitman's deliberate, layered, bifurcated temporality allows a ghostly difference, a haunting deferral, to inhabit the moments that it puts on display. ${ }^{8}$

Joseph's insight applies widely-across and beyond Whitman's oeuvre. Indeed, it is imperative that we recognize a coherent aesthetic project in seemingly diverse works like Shower and Prune Flat. Whitman's neologismsCinema Pieces, Theatre Works - reflect, in part, the absence of a critical terminus able to describe his multimedia practice, let alone link it to related works by other artists, past and present. Such a term is phantasmagoria.

Like Whitman previously, video artist Bill Viola is regularly dismissed as too slick. The criticism is apt, no doubt, but in our non-judgmental review of phantasmagoria, it is beside the point. For few artists have mined the phantasmagoric as rapaciously as Viola. 'In almost all of Viola's works', Otto Neumaier has observed, 'the images become part of the architecture; they exist in space and time. [...] Many of Viola's works are essentially rooms, and it is vital to understand them as such. ${ }^{59}$ Video art leapt into phantasmagoria the moment it occupied entire rooms rather than reduced video to an image in a box. Viola's works are most compelling when they place these two registers in tension: phantasmagoric rooms and domestic boxes. A visitor to his 1988 installation, The Sleep of Reason, likely first encounters a wooden credenza atop which sit a vase with flowers, a lamp, an alarm clock set to the actual time, and a black-and-white television monitor in which one sees the face of a man asleep. At irregular intervals, the room is plunged into darkness, save for the alarm clock, and large, colour, moving images are projected on three walls, accompanied by loud and disquieting sounds. Fires rage, dogs pounce, and owls tear out of the night. The owl and title, of course, are borrowed from Goya's etching, The Sleep of Reason Produces 
Monsters (1799), created at the same time Robertson perfected his own monsters in the Phantasmagoria.

The tension between the two dispositifs is instructive. On the one hand, there is a grainy, black-and-white, diminutive, and nearly motionless image trapped in a box. On the other hand, there is the immersive and jarring seizure of the entire room. In the first instance, video is merely an object in domestic space, like the lamp, the vase, and the alarm clock. In the second instance, the domestic is suspended in favour of a phantasmagoric space for terrifying images and terrified — or at least entertained—viewers. ${ }^{60}$ The inspired touch in the installation is the bridge between these two disparate dispositifs: the alarm clock. Unlike the table lamp or the room's illumination, the red glowing digits of the alarm clock never go black and never deviate from the actual time at the exhibition site. This real time weaves the domestic and phantasmagoric, the quotidian and the oneiric, into one space-time continuum.

The supersession of an object-based conception of video art grounded in the domestic by a phantasmagoric articulation is also in evidence in Set of Coincidence (1974), a single channel video by Peter Campus, a pioneer of video installations. The video opens with Campus, his back to the camera, staring at a television set whose screen displays gray-blue noise. Campus is soon joined by a (blue screen) double and, over the course of several minutes, the two perform a ghostly pas de deux. During the extended dissolve, the original set fades to reveal a blue screen set. As Campus asserted at the time: 'If we are to avoid the problem of creating a visual system that will reduce the capacity of the eye, it is necessary to disassociate the video camera from the eye and make it an extension of the room. ${ }^{61}$ The set of coincidence-where monitor and room coincide - is where the domestic gives way to the phantasmagoric. Here, Campus confronts himself as phantasmal image.

Campus' primary contribution to phantasmagoric video lay in his groundbreaking video installations. Where his single-channel work illustrated, an earlier installation, Interface (1972), performed the very coincidence of looking through and at that was endemic to Pepper's Ghost.

Here the viewer enters a dark, empty room, save for a large pane of glass, with a video camera and projector on either side. As viewers approach the glass, they see a double reflection. The first is a traditional mirror image. The second is real-time, black-and-white video captured through the glass by a camera on the far side. The double-image hovers in the centre of the

6o It nearly goes without saying that the domestic here is staged and that the entire installation retains a phantasmagoric atmosphere, irrespective of the illumination or darkness of the room. 61 Campus, 'Video as a Function of Reality', p. 82. 


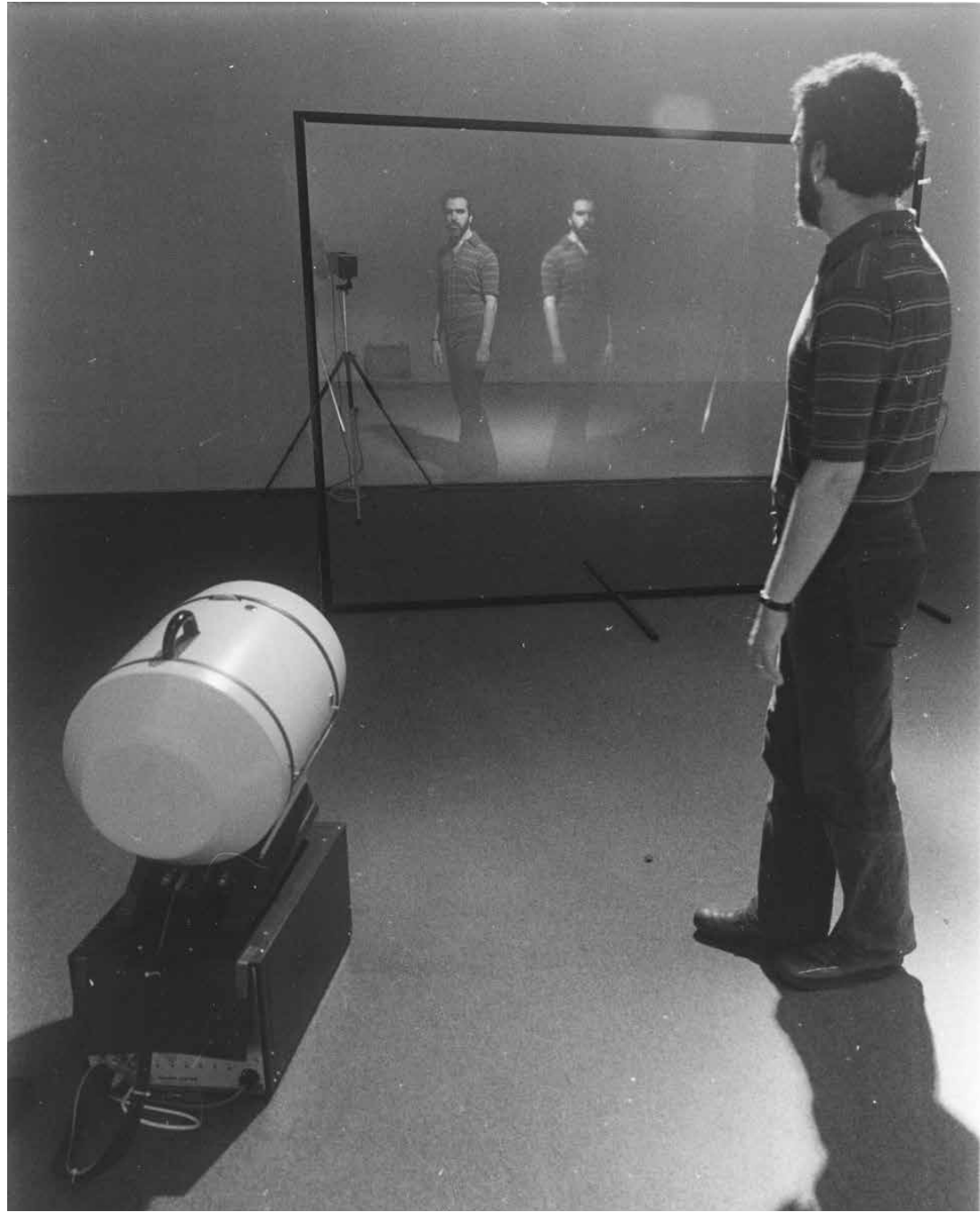

24. Peter Campus. Interface, 1972. Closed circuit video installation. Courtesy of the artist and Cristin Tierney Gallery, New York.

gallery, suspended on a glass screen in real space and real time. Because the video projection corrects for the mirror's left-right reversals, it can appear like a more accurate yet more alien double than the reflection, a reflection let loose, a Doppelgänger-in a word, a ghost. ${ }^{62}$ As Wulf Herzogenrath

62 'Because we are conditioned to a reversed mirror image we are constantly surprised when the direct video image is presented. Any asymmetric movement causes loss of identification with the projected self-image.' Ibid., p. 83 . 
recognized early on, Campus' videos revolve around three main themes: 'double vision, dissolution of material reality, the question of which is the "real" picture'. ${ }^{63}$ Shadow Projection (1974) performs the same ghost story, only with shadows instead of reflections. Interface and Shadow Projection are assemblies of bodies and their phantasms - in a word, phantasmagoria. And as in all phantasmagorias, their fundamental configurations cannot be sought in a single image, medium, technique, device, style, or psychological disorder. Instead, as Campus made clear, "The answer to this is only apparent when the viewer becomes aware of the whole mechanism: the cameraprojector-screen-viewer. ${ }^{64}$ The whole mechanism is nothing less than the phantasmagoric dispositif.

\section{Coda: Occasional Phantasmagorias}

Phantasmagoria still undergirds entire oeuvres. Tony Oursler's, for example, is likely the most diverse and conscientiously phantasmagoric artistic body of work ever produced. Where most artists chanced upon the phantasmagoric dispositif, Oursler has pursued it with the passion of a collector. He has amassed an archive of seminal and obscure books and pamphlets, images and curios, many of which touch on the history of phantasmagoria. ${ }^{65}$ The influence of this archive on his work is pervasive. Most obvious is Oursler's eponymous installation Phantasmagoria (Musée des Arts Contemporains, Hornu, Belgium, 2013), awash in specific historical references to Robertson. No less significant is Imponderable (2015), a new video work on Spiritualism and its debunkers, created for a Pepper's Ghost contraption. Oursler's phantasmagoric magnum opus, of course, is The Influence Machine (2000), a sprawling outdoor installation where lampposts speak, texts run over fences, and faces are projected on buildings, trees, and smoke - the last a technique first employed by Schröpfer in the early 179os, several years before Robertson launched his Phantasmagoria. But Oursler's most original contribution to the contemporary phantasmagoric is also his most enduring and famous technique: the projection of video faces, mouths, and eyes onto dolls, spheres, and other bulbous objects (many of which also speak). In countless video sculptures and video dolls, Oursler anchors moving

63 Herzogenrath, 'Menschen-Bilder/ Picture of People', p. 11.

64 Campus, 'Video as a Function of Reality', p. 83.

65 See Wehr, Imponderable. An earlier and shorter version of this essay appeared as part of the catalogue. 
images in the real world only to blur the boundaries between images and the real world.

Oursler, however, is an exception. More common is the occasional turn to the phantasmagoric. A delirious sampling might include interactive works like Valie Export's Ping Pong. Ein Film zum Spielen - Ein Spielfilm (1968) and David Claerbout's The Rocking Chair (2002-2003), or Rodney Graham's Torqued Chandelier Release (2005), where 35mm 48fps projection on a black screen creates a hallucinatory film loop that is equal parts cinéma pur and phantasmagoria. More systematically, Dan Graham has for decades conjured 'mirror "ghosts"' of spectators in his many glass and steel pavilions. ${ }^{66}$ A work like Two-Way Mirror Inside Cube (1991) is 'both an optical device and an architectural modification of a previously unused [space.] [...] The two-way mirror has "cinematic" special effects. ${ }^{67}$ However much Graham has transformed the parameters of earlier phantasmagoric attractions like Pepper's Ghost, the visual, experiential, and discursive similarities are striking — so long as we recognize that the 'special effects' are not 'cinematic' but consummately phantasmagoric. Examples of phantasmagoric dance or theatre include works like EJM 1-2 (1998), a ballet staged by the architectural duo Elizabeth Diller and Ricardo Scofidio-and co-produced with Charleroi Danses of Belgium and the Ballet Opera of Lyon - which employed rear-projection technology that quite nearly names its debt to the original phantasmagoria; any number of Wooster Group productions, such as their hypermediated rendition of that ultimate ghost story, Hamlet (2005); or Richard Maxwell's Ads (2010), where live actors are replaced with Pepper's Ghost videos. The whole domain of $3 \mathrm{D}$ film - whether mainstream or avant-garde, as in the decades-long pursuit of stereoscopic cinema by Ken Jacobs-demands to be scrutinized in relation to phantasmagoria. ${ }^{68}$ Ultimately, this meager inventory could be multiplied many times over. And much more can and should be said about each of these examples. Suffice to say that, first, the phantasmagoric dispositif can help us account for diverse works otherwise unclassifiable by medium, technique, technology, influence, style, or any of the familiar categories of art and film history and theory. And, second, phantasmagoria is rising.

66 Graham in Alberro, Two-way Mirror Power, pp. 178-179.

67 Graham in ibid., pp. 165-166.

68 The best place to start is Elsaesser, 'The "Return" of 3-D', pp. 217-246. Ken Jacobs himself described The Whole Shebang (1982), one of his Nervous System pieces, in the following terms: 'Phantasmagorical monstrosities pull from the screen. Time doesn't stand still but runs in place'. Jacobs in Schwartz, Films That Tell Time, p. 27. 


\section{Bibliography}

Adorno, Theodor W. (1991). In Search of Wagner, translated by Rodney Livingstone. London: Verso.

Agamben, Giorgio. (2009). What is an Apparatus? and Other Essays, translated by David Kishik and Stefan Pedatella. Stanford, CA: Stanford University Press.

Albera, François, and Maria Tortajada, eds. (2015). Cine-Dispositives: Essays in Epistemology Across Media. Amsterdam: Amsterdam University Press.

Alberro, Alexander, ed. (1999). Two-Way Mirror Power: Selected Writings by Dan Graham on his Art. Cambridge, MA: MIT Press.

Andrew, Dudley. (2010). What Cinema Is! Chichester: Wiley-Blackwell.

Baker, George. (2006). 'Film Beyond its Limits'. Grey Room 25: 92-125.

Balkema, Annette W., and Henk Slager. (2002). Concepts on the Move. Amsterdam: Rodopi.

Barthes, Roland. ([1975] 1980). 'Upon Leaving the Movie Theatre', translated by Bertrand Augst and Susan White. In Apparatus, edited by Theresa Hak Kyung Cha. New York: Tanam Press, pp. 1-4.

Baudry, Jean-Louis. (1986). 'The Apparatus: Metapsychological Approaches to the Impression of Reality in the Cinema', translated by Jean Andrews and Bertrand Augst. In Narrative, Apparatus, Ideology, edited by Philip Rosen. New York: Columbia University Press, pp. 299-318.

Bellour, Raymond. (2012). 'The Cinema Spectator: A Special Memory', translated by Adrian Martin. In Screen Dynamics, edited by Gertrud Koch, Volker Pantenburg, and Simon Rothöhler. Wien: Österreichisches Filmmuseum, pp. 9-21.

_. (2012). La querelle des dispositifs: cinèma - installations, expositions. Paris: P.O.L..

. (2012). Between-the-Images, translated by Allyn Hardyck. Zurich: JRP/ Ringier.

Brewster, David, ed. (1806). Ferguson's Lectures, 2nd ed., 2 vols., vol. 1. Edinburgh: Bell \& Bradfute.

De Bruyn, Eric. (2016). 'Empire's Hologram'. In Cinema in the Expanded Field, edited by François Bovier and Adeena Mey. Zurich: JRP Ringier, pp. 14-53.

_ . (2015). 'Das Holografische Fenster under andere reale Anachronismen'. In Kunstgeschichtlichkeit. Historizität und Anachronie in der Gegenwartskunst, edited by Eva Kernbauer. Paderborn: Fink, pp. 67-98.

Campus, Peter. (2003). 'Video as a Function of Reality' [1974]. In Peter Campus: Analog + Digital Video + Foto, 1970-2003, edited by Wulf Herzogenrath and Barbara Nierhoff. Bremen: Kunsthalle Bremen, pp. 82-83.

Careri, Giovanni. (1995). Bernini: Flights of Love, the Art of Devotion, translated by Linda Lappin. Chicago, IL: University of Chicago Press. 
Casetti, Francesco. (2015). The Lumière Galaxy: Seven Key Words for the Cinema to Come. New York: Columbia University Press.

. (2011). 'Cinema Lost and Found: Trajectories of Relocation'. Screening the

Past 32: http://www.screeningthepast.com/2011/11/cinema-lost-and-foundtrajectories-of-relocation/. (Accessed 17 November 2015).

- (2011). 'Back to the Motherland: the film theatre in the postmedia age'. Screen 52, no. 1: 1-12.

-.(2009). 'Elsewhere. The Relocation of Art'. In Valenciaog/Confines, edited by C. Ciscar Casaban and V. Trione. Valencia: IVAM, pp. 348-351.

Castle, Terry. (1988). 'Phantasmagoria: Spectral Technology and the Metaphorics of Modern Reverie'. Critical Inquiry 15, no. 1 (Autumn): 26-61.

Clark, T.J. (2002). 'Modernism, Postmodernism, and Steam'. October 100 (Spring): 154-74.

Cohen, Margaret. (1989). 'Walter Benjamin's Phantasmagoria'. New German Critique 48: 87-107.

Cooke, Lynne. (2003). 'Through a Glass, Darkly: From Autonomous Artwork to Environmental Spectacle, from Spectator to Specter-Robert Whitman's Art Practice in the 196os'. In Robert Whitman:Playback, edited by Lynne Cooke and Karen Kelly. New York: Dia Art Foundation, pp. 6o-87.

—. (1992). 'Gary Hill: “Who am I but a figure of speech?”' Parkett 34: 16-27.

Cornwell, Regina. (200o). 'Gary Hill: An Interview'. In Gary Hill, edited by Robert C. Morgan. Baltimore, MD: Johns Hopkins University Press, pp. 224-231.

Coscarelli, Joe. (2015). 'Hologram Performance by Chief Keef Is Shut Down by Police'. New York Times, 26 July 2015.

Crary, Jonathan. (2013). 24/7: Late Capitalism and the Ends of Sleep. London/New York: Verso.

—. (2002). 'Géricault, the Panorama, and Sites of Reality in the Early Nineteenth Century'. In Grey Room 9:5-25.

Denby, David. (2007). 'Big Pictures'. The New Yorker, 8 January 2007.

Eckartshausen, Karl von. (1788). Aufschlüsse zür Magie. Brünn:J.S. Siedler.

Elcott, Noam. (2016). Artificial Darkness: An Obscure History of Modern Art and Media. Chicago, IL: University of Chicago Press.

Elsaesser, Thomas. (2015). 'Between Knowing and Believing'. In Cine-Dispositives, edited by François Albera and Maria Tortajada. Amsterdam: Amsterdam University Press.

— (2013). "The "Return" of 3-D: On Some of the Logics and Genealogies of the Image in the Twenty-First Century'. Critical Inquiry 29, no. 2: 217-246.

Elwes, Catherine. (2015). Installation and the Moving Image. New York: Columbia University Press. 
Friedman, Martin. (1974). 'The Floating Picture Plane'. In Projected Images, edited by Martin Friedman et al. Minneapolis, MN: Walker Art Centre, pp. 6-7.

Gidal, Peter. (1976). 'Theory and Definition of Structural/Materialist Film'. In Structural Film Anthology, edited by Peter Gidal. London: BFI, pp. 1-21. - (1971). Andy Warhol. London: Studio Vista.

Grau, Oliver. (2007). 'Remember the Phantasmagoria! Illusion Politics of the Eighteenth Century and Its Multimedia Afterlife'. In MediaArtHistories, edited by Oliver Grau. Cambridge, MA: MIT Press, pp. 137-161.

Gunning, Tom. (2004). 'Phantasmagoria and the Manufacturing of Illusions and Wonder: Towards a Cultural Optics of the Cinematic Apparatus'. In The Cinema, A New Technology for the 2oth Century, edited by André Gaudreault, Catherine Russell, and Pierre Véronneau. Lausanne: Editions Payot, pp. 31-44.

Hanhardt, John G. (2000). 'Between Language and the Moving Image: The Art of Gary Hill'. In Gary Hill, edited by Robert C. Morgan. Baltimore, MD: Johns Hopkins University Press, pp. 114-121.

Harms, Rudolf. (1926). Philosophie des Films. Leipzig: Felix Meiner.

Herzogenrath, Wulf. (1979). 'Menschen-Bilder/ Picture of People', translated by John Anthony Thwaites. In Peter Campus: Video-Installationen, Foto-Installationen, Fotos, Videobänder. Cologne: Kölnischer Kunstverein, pp. 8-11.

Jäger, Joachim, Gabriele Knapstein, and Anette Hüsch, eds. (2006). Beyond Cinema: The Art of Projection. Berlin: Hatje Cantz.

Jennings, Michael W. (2003). 'On the Banks of a New Lethe: Commodification and Experience in Benjamin's Baudelaire Book'. boundary 2 30, no. 1: 89-104.

Joseph, Branden W. (2006). 'Plastic Empathy: The Ghost of Robert Whitman'. Grey Room 25: 64-91.

Kostelanetz, Richard. (1968). The Theatre of Mixed Means. New York: Dial Press.

Krajewski, Markus. (2013). 'The Power of Small Gestures: On the Cultural Technique of Service'. Theory, Culture \& Society 30, no. 6: 94-109.

Lubbock, Tom. (1993). 'Is there someone out there?'. The Independent, 21 December 1993.

Mannoni, Laurent. (2000). The Great Art of Light and Shadow, translated by Richard Crangle. Exeter: University of Exeter Press.

McCall, Anthony. (2003). 'Line Describing a Cone and Related Films'. October 103: $42-62$.

— . ([1974/75] 1978). 'Two Statements'. In The Avant-Garde Film: A Reader of Theory and Criticism, edited by P. Adams Sitney. New York: New York University Press, pp. 250-254.

McCarthy, Anna. (2001). 'From Screen to Site: Television's Material Culture, and Its Place'. October 98: 93-111. 
Mondloch, Kate. (2010). Screens: Viewing Media Installation Art. Minneapolis, MN: University of Minnesota Press.

Monte, James. (1969). 'Anti-Illusion: Procedures/Materials'. In Anti-Illusion:Procedures/Materials, edited by Marcia Tucker and James Monte. New York: Whitney Museum, pp. 4-17.

Morgan, Robert C. (200o). 'Gary Hill: Beyond the Image'. In Gary Hill, edited by Robert C. Morgan. Baltimore, MD: Johns Hopkins University Press, pp. 1-14.

Morgan, Stuart. (1993). 'Missing Persons'. In Gary Hill: In Light of the Other, edited by Chrissie Iles and Lewis Biggs. Oxford: Museum of Modern Art Oxford/Tate, pp. 22-26.

Nead, Lynda. (2007). The Haunted Gallery: Painting, Photography, Film c.19oo. New Haven, CT: Yale University Press.

Neumaier, Otto. (2004). 'Space, Time, Video, Viola'. In The Art of Bill Viola, edited by Chris Townsend. London: Thames \& Hudson, pp. 46-71.

Paech, Joachim. (1991). 'Eine Dame verschwindet: Zur dispositiven Struktur apparativen Erschienens'. In Paradoxien, Dissonanzen, Zusammenbrüche. Situationen offener Epistemologie, edited by Hans Ulrich Gumbrecht and K. Ludwig Pfeiffer. Frankfurt am Main: Suhrkamp, pp. 773-79o.

Quasha, George, and Charles Stein. (2009). An Art of Limina: Gary Hill's Works and Writings. Barcelona: Ediciones Polâigrafa.

Robertson, Étienne Gaspard. (1831-1833). Mémoires récréatifs, scientifiques et anecdotiques. 2 vols., vol. 1. Paris: Chez l'auteur et à la Librairie de Wurtz.

Rodowick, David N. (1994). The Crisis of Political Modernism. Berkeley, CA: University of California Press.

Schmidt, Gunnar. (2011). Weiche Displays: Projektionen aufRauch, Wolken und Nebel. Berlin: Verlag Klaus Wagenbach.

Schroeter, Jens. (2014).3D: History, Theory, and Aesthetics of the Transplane Image, translated by Brigitte Pichon and Dorian Rudnytsky. New York: Bloomsbury.

Schwartz, David, ed. (1989). Films That Tell Time: A Ken Jacobs Retrospective. New York: American Museum of the Moving Image.

Siegert, Bernhard. (2014). 'Die Leiche in der Wachsfigur. Exzesse der Mimesis in Kunst, Wissenschaft und Medien'. In Untot. Existenzen zwischen Leben und Leblosigkeit, edited by Peter Geimer. Berlin: Kadmos, pp. 116-135, 228-231.

Tresch, John. (2011). 'The Prophet and the Pendulum: Sensational Science and Audiovisual Phantasmagoria around 1848'. Grey Room 43:16-21.

Uroskie, Andrew V. (2014). Between the Black Box and the White Cube: Expanded Cinema and Postwar Art. Chicago, IL: University of Chicago.

Virilio, Paul. ([1988] 1994). The Vision Machine, translated by Julie Rose. Bloomington, IN: Indiana University Press. 
von Eckartshausen, Carl. (1791). Aufschlüsse zur Magie aus geprüften Erfahrungen über verborgene philosophische Wissenschaften und verdeckte Geheimnisse der Natur. Vol. 1. Lentner.

Wagner, Richard. ([1849] 1895). 'The Art-Work of the Future', translated by William Ashton Ellis. In his Richard Wagner's Prose Works. St. Clair Shores, MI: Scholarly Press, reprint 1972.

Wagner, Richard. (1850). Das Kunstwerk der Zukunft. Leipzig: Otto Wigand.

Warner, Marina. (2006). Phantasmagoria: Spirit Visions, Metaphors, and Media into the Twenty-first Century. Oxford: Oxford University Press.

Wehr, Anne, ed. (2015). Imponderable: The Archive of Tony Oursler. Zurich: LUMA Foundation.

Williams, Raymond. (1974). Television: Technology and Cultural Form. New York: Schocken.

Wittkower, Rudolf. (1990). Bernini: The Sculptor of the Roman Baroque. Rome: Banco di Santo Spirito.

Youngblood, Gene. (1970). Expanded Cinema. New York: Dutton.

\section{About the Author}

Noam M. Elcott is Associate Professor of Art History and Archaeology at Columbia University, Chair of Art Humanities, an editor of the journal Grey Room, co-director of the Center for Comparative Media at Columbia University, and co-director of The August Sander Project (MoMA/Columbia). He is the author of Artificial Darkness: An Obscure History of Modern Art and Media (University of Chicago Press, 2016), winner of the 2017 Society for Cinema and Media Studies (SCMS) Anne Friedberg Innovative Scholarship Award, as well as the writer of essays on art, film, and media that have been published in leading journals, anthologies, and exhibition catalogues. His current book project is Art in the First Screen Age: László Moholy-Nagy and the Cinefication of the Arts (University of Chicago Press). 
